\title{
Gaining perspective on SUDEP
}

\author{
The new guideline
}

Barbara A. Dworetzky, MD

Jaideep Kapur, MD, PhD

Correspondence to

Dr. Dworetzky:

bdworetzky@partners.org

Neurology ${ }^{\circledR} 2017 ; 88: 1598-1599$

Epilepsy is one of the most common neurologic disorders, affecting people of all ages and backgrounds. It is often burdensome, even when seizures are controlled: patients generally require daily costly medications with adverse effects and have higher rates of depression, anxiety, and cognitive disturbances. While there are many available treatments, about one-third of patients continue to have seizures, which imposes greater burdens by restricting the ability to drive, creating underemployment or unemployment, decreasing fertility and marriage rates, lowering quality of life, and causing higher morbidity. In addition, people with uncontrolled epilepsy have increased mortality, with the highest risk from sudden unexpected death in epilepsy (SUDEP), which preferentially targets young people. ${ }^{1}$ Growing concern about this devastating outcome is reflected in increasing publications devoted to understanding and preventing SUDEP, and calls for action to inform patients about SUDEP. ${ }^{2}$ Many risk factors have been reported but not substantiated, leading to an overestimation of individual risk. Further, conflicting reports of increased SUDEP incidence in patients taking common medications such as lamotrigine, ${ }^{3}$ or while in a placebo arm of a drug trial, ${ }^{4}$ or with low drug levels, leads to much confusion. It is in this context that the American Academy of Neurology (AAN) and the American Epilepsy Society joined to create a guideline to define incidence of SUDEP in children and adults as well as risk factors in order to provide ways to mitigate this risk and to face discomfort with these difficult conversations.

In their practice guideline summary in this issue of Neurology ${ }^{\circledR}$, Harden et al..$^{5}$ review relevant Class I and II studies from the growing literature on SUDEP to address concerns of patients and those who care for them. They provide consensus-based recommendations using the standard AAN process. Four Class I studies, focusing only on children, found the incidence of SUDEP to be $0.22 / 1,000$ patient-years ( $95 \%$ confidence interval [CI] 0.16-0.31), with high confidence in the evidence. Eight Class I studies found the incidence of SUDEP in adults to be 1.2/1,000 patientyears (95\% CI $0.64-2.32)$, but with low confidence due to too much heterogeneity uncovered in metaanalyses. The panel also attempted to determine the incidence in the subset of difficult-to-treat patients (1 Class I study showed 1.5/1,000 patient-years) and pregnant patients $(0.79 / 1,000$ patient-years) with epilepsy, but precision was low after meta-analysis.

Second, the guideline focused on risk factors for SUDEP, confirming high confidence in Class II evidence for generalized tonic-clonic seizures as a risk factor, especially if they are frequent, with an exponential rise in risk (Level A). Due to the dose-responsive nature of the findings, the authors concluded that there was high confidence in this risk factor and made an inference as to its causative nature. Continued management of convulsions, including nocturnal supervision, was associated with diminished risk of SUDEP.

The strengths of this practice guideline include the sound methodology, the large number of Class I and II studies, and the many practical consensus recommendations, such as informing patients and families about the risk of SUDEP and its low yearly risk (i.e., "999/ 1,000 adults will not be affected”: Level B). Clinicians should inform patients that eliminating convulsions is strongly associated with a decreased risk of SUDEP. This may help some patients move on to the next treatment rather than remaining on one that is clearly no longer working as well as it should.

There are some limitations to this guideline. The authors found insufficient evidence to determine many of the proposed risk factors, but this does not necessarily mean that they are not risk factors. It is difficult to study SUDEP incidence and risk: this requires a great deal of effort to gather a large dataset, as this is an infrequent event that generally occurs out of the physician's purview. Areas of concern that are not addressed in the guideline include when to inform patients that they are at risk of SUDEP, and how to safely address dose reductions, which may carry an elevated risk of SUDEP. Within the confines of the epilepsy monitoring unit (EMU), safety measures include cardiac monitoring, placement of a peripheral IV line with a plan for rescue medication, and maintaining the patient under observation. Understanding 
the risk of recurrent convulsion at the time of discharge from the EMU is important information that is currently unknown.

This guideline is an important first step for epilepsy practice. It begins to put the risk of SUDEP into perspective by challenging the strength of evidence for many of the risk factors reported in the literature. Patients and families may find this information reassuring as we look for ways to target specific subsets of patients at risk. A key step in reducing the incidence of SUDEP is to understand pathophysiologic mechanisms. Clues regarding pathophysiology have emerged from studying SUDEP and near-SUDEP events in the EMU. ${ }^{6}$ The authors propose that neuronal networks generating generalized tonic-clonic seizures compromise brainstem respiratory or autonomic control centers, leading to hypoventilation and autonomic dysregulation. In addition, normal arousal mechanisms may be compromised in these individuals. Children with Dravet syndrome have an unusually high risk of SUDEP. Mutations in sodium channel gene $S C N 1 A$ are the most common cause of Dravet syndrome and this gene is expressed in brain and heart. It is possible that these mutations render patients more susceptible to cardiac arrhythmias in the setting of a seizure. ${ }^{7}$ More research is needed to identify genetic and other risk factors, causes, and methods for preventing SUDEP. The Center for SUDEP Research (csr.case.edu/), funded by NIH and a group of voluntary organizations, is a much-needed, cross-disciplinary collaborative effort. However, the vital partnership of researchers, clinicians, medical examiners, coroners, pathologists, and patients and their families is also necessary for the ultimate goal of preventing SUDEP.

\section{STUDY FUNDING}

No targeted funding reported.

\section{DISCLOSURE}

Dr. Dworetzky reports no disclosures. Dr. Kapur receives NIH funding for his research. Go to Neurology.org for full disclosures.

\section{REFERENCES}

1. Devinsky O, Hesdorffer DC, Thurman DJ, Lhatoo S, Richerson G. Sudden unexpected death in epilepsy: epidemiology, mechanisms, and prevention. Lancet Neurol 2016;15:1075-1088.

2. Xu Z, Ayyappan S, Seneviratne U. Sudden unexpected death in epilepsy (SUDEP): what do patients think? Epilepsy Behav 2015;422:29-34.

3. Tomson T, Hirsch LJ, Friedman D, et al. Sudden unexpected death in epilepsy in lamotrigine randomized-controlled trials. Epilepsia 2013;54:135-140.

4. Ryvlin P, Cucherat M, Rheims S. Risk of sudden unexpected death in epilepsy patients given adjunctive antiepileptic treatment for refractory seizures: a meta-analysis of placebo controlled randomized trials. Lancet Neurol 2011;10:961-968.

5. Harden C, Tomson T, Gloss D, et al. Practice guideline summary: sudden unexpected death in epilepsy incidence rates and risk factors: report of the Guideline Development, Dissemination, and Implementation Subcommittee of the American Academy of Neurology and the American Epilepsy Society. Neurology 2017;88:1674-1680.

6. Ryvlin P, Nashef L, Lhatoo SD, Bateman LM, et al. Incidence and mechanisms of cardiorespiratory arrests in epilepsy monitoring units (MORTEMUS): a retrospective study. Lancet Neurol 2013;12:966077.

7. Shmuely S, Sisodiya SM, Gunning WB, Sander JW, Thijs RD. Mortality in Dravet syndrome: a review. Epilepsy Behav 2016;64:69-74. 


\title{
Neurology
}

\author{
Gaining perspective on SUDEP: The new guideline \\ Barbara A. Dworetzky and Jaideep Kapur \\ Neurology 2017;88;1598-1599 \\ DOI 10.1212/WNL.0000000000003698
}

This information is current as of April 24, 2017

\section{Updated Information \& Services}

\section{References}

Subspecialty Collections

\section{Permissions \& Licensing}

\section{Reprints}

including high resolution figures, can be found at: http://n.neurology.org/content/88/17/1598.full

This article cites 7 articles, 1 of which you can access for free at: http://n.neurology.org/content/88/17/1598.full\#ref-list-1

This article, along with others on similar topics, appears in the following collection(s):

All Epilepsy/Seizures

http://n.neurology.org/cgi/collection/all_epilepsy_seizures All Pediatric

http://n.neurology.org/cgi/collection/all_pediatric

Incidence studies

http://n.neurology.org/cgi/collection/incidence_studies

Risk factors in epidemiology

http://n.neurology.org/cgi/collection/risk_factors_in_epidemiology

Information about reproducing this article in parts (figures,tables) or in its entirety can be found online at:

http://www.neurology.org/about/about_the_journal\#permissions

Information about ordering reprints can be found online:

http://n.neurology.org/subscribers/advertise

Neurology ${ }^{\circledR}$ is the official journal of the American Academy of Neurology. Published continuously since 1951, it is now a weekly with 48 issues per year. Copyright (O 2017 American Academy of Neurology. All rights reserved. Print ISSN: 0028-3878. Online ISSN: 1526-632X.

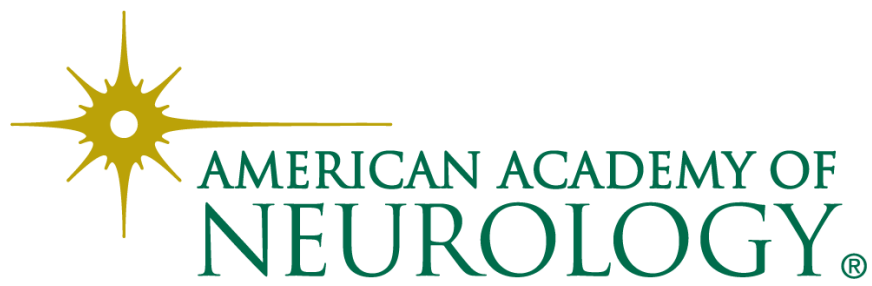

